\title{
CRANIOCERVICAL JUNCTION DISEASES TREATMENT WITH A MINIMALLY INVASIVE APPROACH
}

\author{
ABORDAGEM MINIMAMENTE INVASIVA PARA TRATAMENTO DE LESÕES DA UNIÃO \\ CRANIOCERVICAL
}

\section{ABORDAJE MINIMAMENTE INVASIVO PARA TRATAMIENTO DE LESIONES DE LA UNION CRANEOCERVICAL}

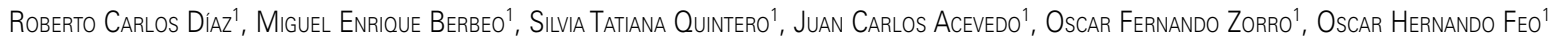

\begin{abstract}
Objective: To introduce a new minimally invasive surgical approach to anterior and lateral craniocervical junction diseases, preserving the midline posterior cervical spine stabilizing elements and reducing the inherent morbidity risk associated with traditional approaches. Methods: We describe a novel surgical technique in four cases of extra-medullary anterolateral compressive lesions located in the occipito-cervical junction, including infections and intra- and/or extradural tumor lesions. We used a paramedian trasmuscular approach through an anatomical muscle corridor using a micro MaXcess ${ }^{\circledR}$ surgical expandable retractor, with the purpose of reducing morbidity and preserving the posterior muscle and ligamentous tension band. Results: This type of surgical approach provides adequate visualization and microsurgical resection of lesions and reduces muscle manipulation and devascularisation, preserving the tension of the ligament complex. There was minimal blood loss and a decrease in postoperative pain, with rapid start of rehabilitation and shorter hospitalization times. There were no intraoperative complications, and all patients recovered from their pre-operative symptoms. Conclusions: This novel surgical technique is feasible and adequate for the occipito-atlanto-axial complex, with better results than traditional procedures.
\end{abstract}

Keywords: Spine; Cervical vertebrae; Laminectomy; Microsurgery; Surgical procedures, minimally invasive; Spinal neoplasms.

\begin{abstract}
RESUMO
Objetivo: Realizamos esforços para desenvolver novas técnicas cirúrgicas para reduzir a morbidade e a mortalidade. Métodos: Descrevemos uma técnica cirúrgica nova em quatro casos de lesões extramedulares compressivas anterolaterais da junção occipitocervical, que incluem infecções e lesões tumorais intra e extradurais. As lesões foram excisadas por uma nova técnica cirúrgica minimamente invasiva, por meio de um corredor anatômico muscular, utilizando-se o afastador expansível MaXcess ${ }^{\circledR}$ (Nuvasive Inc., San Diego, CA, EUA) visando reduzir a morbidade e preservar a banda de tensão músculo-ligamentar. Resultados: Esse tipo de abordagem proporcionou visualização e excisão microcirúrgica adequada das lesões, com redução da manipulação muscular, preservando a tensão do complexo ligamentar nucal. Houve perda de sangue mínima, além da redução da dor pós-operatória, início rápido da reabilitação e pequena estadia hospitalar. Não foram observadas complicações intraoperatórias e os pacientes não tiveram mais os sintomas apresentados no pré-operatório. Conclusões: Essa nova técnica cirúrgica é uma opção de tratamento na região do complexo occipito-atlanto-axial anterolateral, com resultados superiores aos dos procedimentos tradicionais.
\end{abstract}

Descritores: Coluna vertebral; Vértebras cervicais; Laminectomia; Microcirurgia; Procedimentos cirúrgicos minimamente invasivos; Neoplasias da coluna vertebral.

\section{RESUMEN}

Objetivo: Se han realizado esfuerzos por desarrollar nuevas técnicas quirúrgicas que reduzcan morbimortalidad. Métodos: Describimos una novedosa técnica quirúrgica de tratamiento en cuatro casos de lesiones extramedulares compresivas anterolaterales de la unión occipitocervical que incluyen infecciones y lesiones tumorales intra y extradurales. Las lesiones fueron extirpadas por una nueva técnica quirúrgica mínimamente invasiva a través de un corredor anatómico muscular, utilizándose el retractor expansible MaXcess ${ }^{\circledR}$ (Nuvasive Inc., San Diego, CA, EEUU) con el objetivo de reducir la morbilidad y preservar la banda de tensión músculo-ligamentaria. Resultados: Este tipo de abordaje aportó adecuada visualización y resección microquirúrgica de las lesiones, con reducción de la manipulación muscular, presenvando la tensión del complejo ligamentario nucal. Hubo mínima pérdida sanguínea además de disminución de dolor post-operatorio, rápido inicio de rehabilitación y corta estancia hospitalaria. No se presentaron complicaciones intraoperatorias y los pacientes se recuperaron de la sintomatología preoperatoria. Conclusiones: Esta nueva técnica quirúrgica se perfila como una opción de tratamiento a nivel del complejo occipito-atlanto-axial anterolateral con resultados superiores a los procedimientos tradicionales.

Descriptores: Columna vertebral; Vértebras cervicales; Laminectomía; Microcirugía; Procedimientos quirúrgicos mínimamente invasivos; Neoplasias de la columna vertebral.

\section{INTRODUCTION}

The craniocervical junction is considered to be a biomechanical and functional unit comprising bony, ligamentary, and soft tissue structures on which craniospinal structural stability and the integrity of vitally important neurovascular structures depend. ${ }^{1}$ The study of the anatomy of these structures in clinical pathology and surgery justifies the implementation of new techniques for approaches at

1. Hospital Universitario San Ignacio, Pontificia Universidad Javeriana, Bogotá, Colombia.

Study conducted at the Neurosurgery Unit, Department of Neurosciences, Hospital Universitario San Ignacio, Pontificia Universidad Javeriana, Bogotá, Colombia.

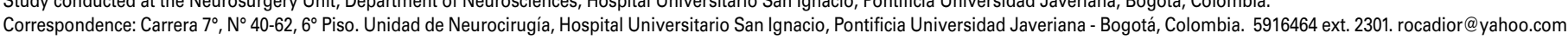


this level. Over the last ten years, these concepts have influenced surgical procedure plans for the resection of tumors, traumatic pathology, and degenerative diseases. ${ }^{2-7}$

Technological advances in neuroimaging, microsurgical instruments, and minimally invasive surgery have enabled the development of new approaches that maintain the favorable neurological outcomes achieved using conventional spinal neoplasia resection techniques. Additionally, these approaches preserve the midline and posterior spinal structures, reducing the risk of post-operative instability, with less damage to the soft tissues, less blood loss, minimal post-operative pain, and a short hospital stay. ${ }^{2-5,7-13}$

Success in the approach to injuries of the craniocervical junction is based on knowledge of the dynamics of this unit. Anatomical studies of this area stress the importance of preserving both the paraspinal muscular structures and the anterior and posterior ligaments, to insure adequate post-operative stability. ${ }^{1}$ Our study describes a new surgical technique for the resection of anterolateral, compressive, intra- and extradural, extramedullary lesions of the craniocervical junction, through an anatomical transmuscular paramedian corridor, using the MaXcess ${ }^{\circledR}$ (Nuvasive Inc., San Diego, CA, USA) micro-retractor with the aim of reducing morbidity and preserving the posterior muscular ligamentous tension band.

\section{MATERIALS AND METHOD}

We present a case report of a patient with intra and extradural, intra-rachidian, extramedullary lesions located in the anterolateral region of the craniocervical junction, with the objective of evaluating the surgical anatomy and the feasibility of the approach for injuries at this level. Clinical follow-up was conducted, and patients treated between January 2009 and December 2011 were included. Surgical time, blood loss, intra-operative and post-operative complications, hospitalization time, and pre- and post-operative neurological status were recorded. ${ }^{14}$

\section{Surgical Technique}

Under general anesthesia, the patient is positioned in prone decubitus, with the head fixed in the neutral position using a Mayfield-type three-pin support. The alignment of the C1 - C2 complex is confirmed using a fluoroscopic guide. A $3 \mathrm{~cm}$ linear paramedian incision is made, two centimeters from the midline, ipsilaterally to the location of the lesion, to expose the outer surface of the muscle. (Figure 1) A transmuscular digital dissection was performed through the trapezius and semispinalis capitis; deeper, following a line parallel to the spinous process of C2, an anatomical corridor was found, formed by the angle between the rectus capitis posterior minor and the obliquus capitis inferior muscles. (Figure 2) There are no important vascular or neural structures at this level. Guided by fluoroscopy, the first tubular dilator is positioned in this corridor and then the other dilators are gradually inserted. Finally, the Micro MaXcess ${ }^{\circledR}$ retractor, which has its own light source, is positioned and secured. (Figure 3) The C2 - C3 articulation, the lamina, and the pedicle are observed under high magnification. Sometimes residual vascular tissue is found at this level and can be submitted to monopolar or bipolar resection. Once the bone surface is exposed at a $30^{\circ}$ angle, a hemilaminectomy of $\mathrm{C} 2$ is performed, with 1 and $2 \mathrm{~mm}$ Kerrison punches, identifying and resecting the ligamentum flavum, and observing the lateral outer surface of the dural sac. Depending on the case, the lesion is microsurgically resected or drained. (Figure 4) Hemostasis with Gelfoam and irrigation with saline solution are performed. In the event of dural opening, closure is performed using fibrin sealant and an autologous fat graft.

\section{Case History}

Patient, 39 years of age, who began to experience numbness of the right hand one year prior to the consultation, and which had spread bilaterally to the arms, abdomen, and legs over the last few months. The patient also presented clumsiness of the hands and

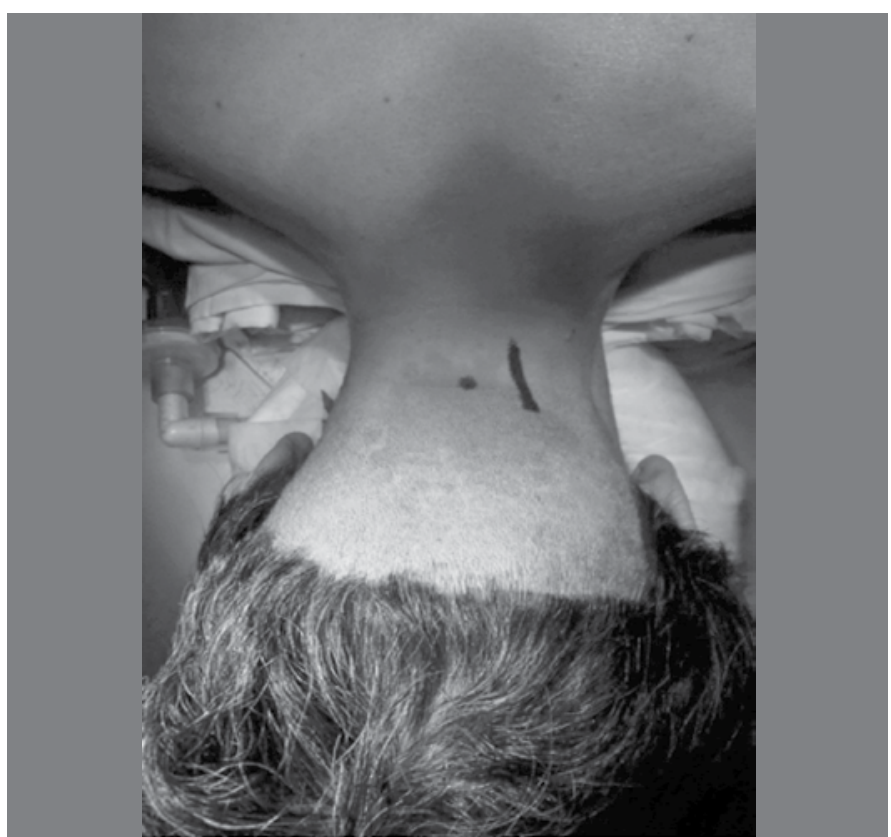

Figure 1. Incision. Patient in prone decubitus, head on a Mayfield-type three-pin support. The alignment of the $\mathrm{C} 1-\mathrm{C} 2$ complex is confirmed using a fluoroscopic guide. A $3 \mathrm{~cm}$ linear paramedian incision is made two centimeters from the midline, ipsilaterally to the site of the lesion.

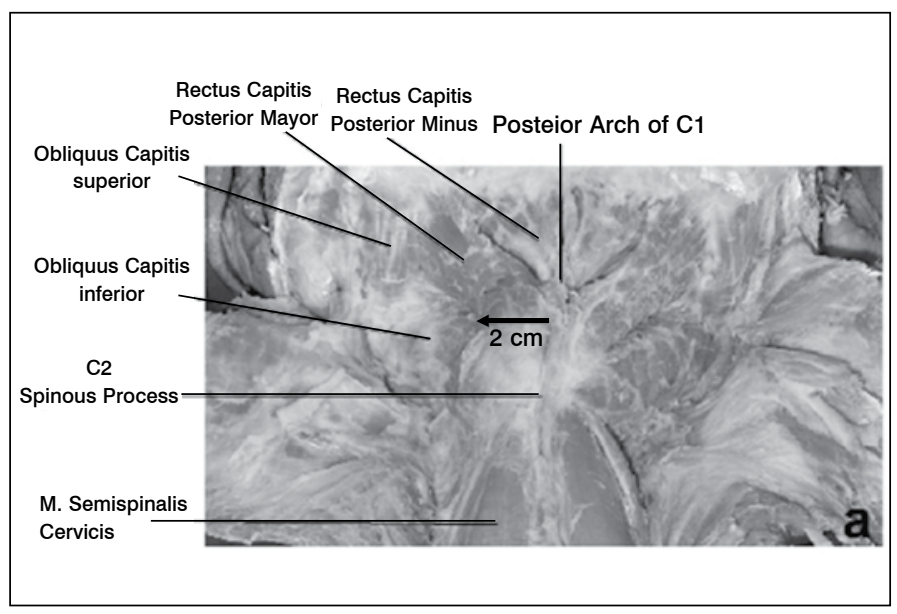

Figure 2. Anatomical Corridor. Anatomical corridor located 2 centimeters from the spinous process of $\mathrm{C} 2$, formed by the angle between the rectus capitis posterior minor and obliquus capitis muscles.

changes in gait. The neurological exam revealed hypoesthesia with sensory level $\mathrm{C} 4$, spastic paraparesis at $\mathrm{C} 4-\mathrm{C} 5$, changes in proprioception, osteotendinous hyperreflexia of the four extremities, and Hoffman, Trommer, and Babinski signs.

Simple and contrast magnetic resonance of the craniospinal junction was performed, revealing an intradural, extramedullary lesion in the anterolateral region of the spinal cannel at the $\mathrm{C} 1-\mathrm{C} 2$ level, causing severe compression of the spinal cord and the nerve roots. Resection of the lesion was performed using the surgical technique described, with no complications, a surgical time of 4 hours and 10 minutes, blood loss of $500 \mathrm{cc}$, and the complete improvement of the numbness and recovery of the sensory level in the immediate post-operative period. Hospital discharge after 36 hours with appropriate evolution. In the follow-up visit one week after the procedure, the symptoms were completely resolved and there was minimal post-operative pain. Cervical resonance was performed a month later as a control and there was no evidence of any residual tumor causing compression. 

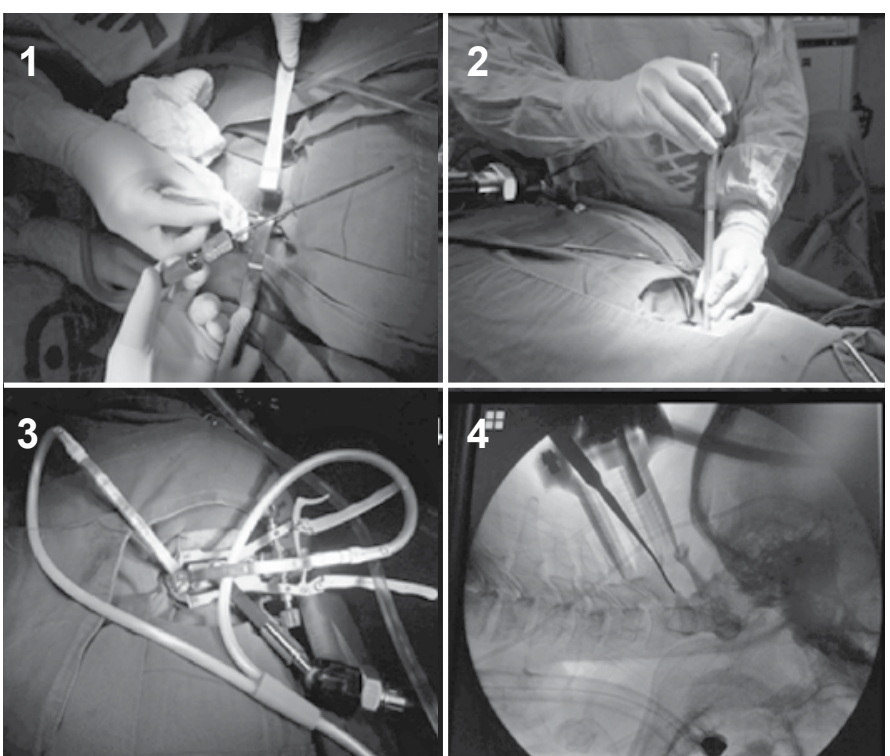

Figure 3. Surgical Technique. Digital transmuscular dissection down to the lamina of C2 (1). Muscular dilators are placed sequentially through the identified muscular corridor under fluoroscopic guidance (2). The separator is positioned using the Micro MaXcess $₫$ retractor which has its own light source (3). The position of the separator above the lamina of $\mathrm{C} 2$ is verified (4).

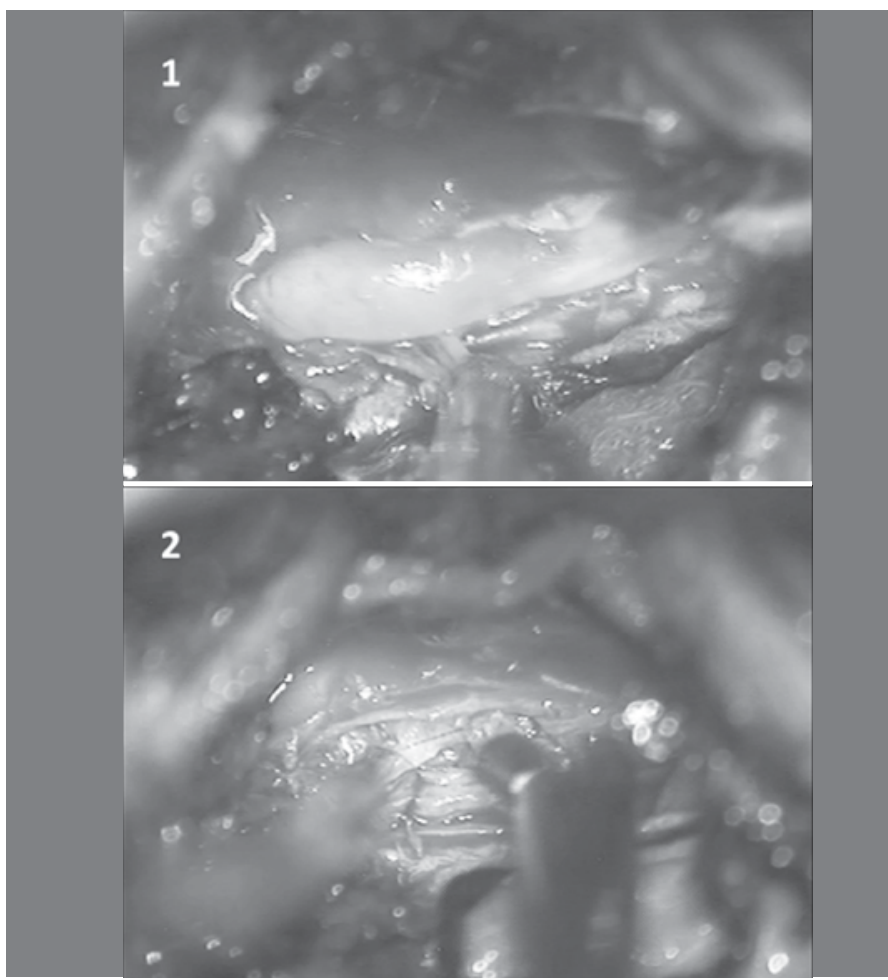

Figure 4. Microsurgical View. In this highly magnified view at an angle of 30 degrees, the lateral surface of the dural sac can be observed (1). The lesion is resected or drained using a microsurgical technique (2).

\section{RESULTS}

Between January 2009 and December 2011 four patients (two men and two women) underwent surgical procedures using this technique. All the lesions were located in the anterolateral region of the craniocervical junction. Two patients had extradural tumors, one patient had an intradural tumor, and one patient had an extradural abscess. There were no intra- or post-operative complications. All the patients (100\%) recovered adequately from their pre-operative symptoms. Average intra-operative bleeding was 203.5 cc. The patients experienced minimal post-operative pain and were discharged after an average of 46.8 hours following surgery. There were no associated cases of infection. (Figure 5)

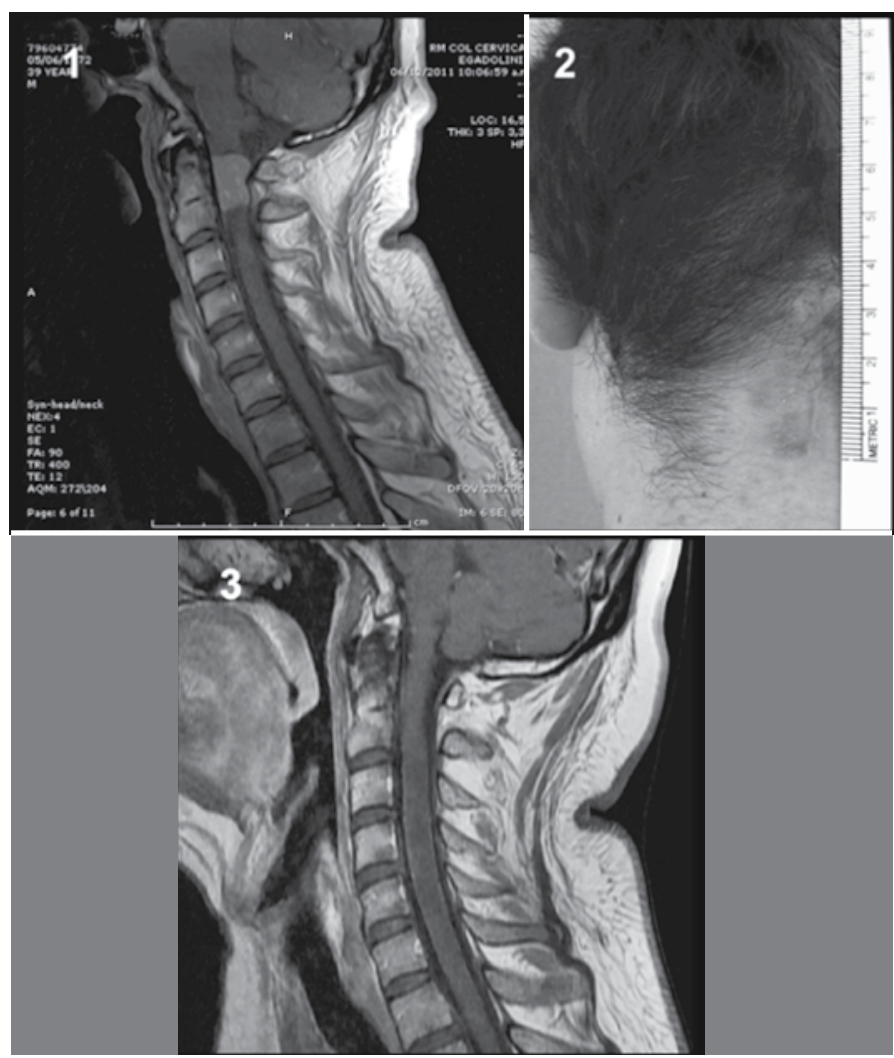

Figure 5. Results. Pre-surgical image (1), post-operative scar (2), post-operative image (3).

\section{DISCUSSION}

The current trend in spinal neurosurgery is for minimally invasive surgery. Multiple previous studies have established a valid justification for this type of approach with similar results in terms of resected volume, neurological outcomes, and conservation of structures essential to the biomechanics of the spine. . $^{\text {-11,15-18 }}$

Minimally invasive approaches have been developed for degenerative pathology $4,5,18-21$ and for some predominantly thoracolumbar neoplasias. ${ }^{1,7-11,13,16,17,22-24}$ This development has been associated with technological advances in minimally invasive techniques. Our review of the literature on approaches to resection of spinal tumors found few studies of the craniocervical junction or upper cervical spine levels, and those that were reviewed involved anterior or anterolateral approaches requiring total or partial corpectomy. ${ }^{14,25,26}$ However, other authors believe that posterior approaches are safer and avoid the complications of the anterior approach, such as visceral or vascular damage or recurrent paralysis of the laryngeal nerve. ${ }^{19,25,27,28} \mathrm{Re}$ ports of minimally invasive posterior approach techniques for tumors suggest the need to perform hemilaminectomy, subtotal hemilaminectomy, of interlaminar fenestration in all cases with midline incisions and dissections. ${ }^{2,9,10,13,29}$ These approaches involve disinsertion of the paraspinal musculature and ligamentary structures, though to a lesser extent than traditional techniques. Unlike both the traditional and minimally invasive approaches reported in the literature, our approach is performed via the paramedian route, through an anatomical muscle corridor, reducing further damage to the paravertebral soft tissue and preserving the craniocervical band. Besides this being a paramedian approach, it allows a $30^{\circ}$ entry angle for anterolateral lesions, which is difficult to achieve with traditional approaches. 
This approach offers an alternative to traditional treatment of the anterolateral spinal occipito-atlas-axis complex level because it demonstrates good results in terms of the volume of the lesion resected, the post-operative neurological evolution, less blood loss, less post-operative pain, and shorter hospitalization times.

\section{CONCLUSION}

Our surgical technique involves a minimally invasive posterior paramedian approach, based on the description of a new anatomical transmuscular paraspinal posterolateral corridor that promotes less surgical injury and simplifies access to the craniocervical junction. This new approach is useful not only in tumor pathology, but also in the management of degenerative or traumatic diseases at this level. This surgical technique has not been previously recorded in the literature for the resection of compressive intraspinal lesions at this level, and may be extremely useful for the development of new treatment alternatives. We believe, as in the literature reviewed, that minimally invasive surgery requires special training in these techniques and should be performed by groups with sufficient experience to achieve reproducible results. ${ }^{3,7,15}$ The continuation of this study and future contributions will establish this technique as a key alternative within the area of spinal surgery.

\section{ACKNOWLEDGMENTS}

We would like to thank the directors of the Facultad de Medicina de la Pontificia Universidad Javeriana, and of the Hospital Universitario San Ignacio, Colombia, for supporting the neurosurgery team in their development of new surgical advances.

All authors declare no potential conflict of interest concerning this article.

\section{REFERENCES}

1. Tubbs RS, Hallock JD, Radcliff V, Naftel RP, Mortazavi M, Shoja MM, et al. Ligaments of the craniocervical junction. J Neurosurg Spine. 2011:14(6):697-709.

2. Dehcordi SR, Marzi S, Ricci A, Di Cola F, Galzio RJ. Less invasive approaches for the treatment of cervical schwannomas: our experience. Eur Spine J. 2011;21(5):887-96.

3. Fessler RG, O'Toole JE, Eichholz KM, Perez-Cruet MJ. The development of minimally invasive spine surgery. Neurosurg Clin N Am. 2006:17(4):401-9.

4. Franke J, Greiner-Perth R, Boehm H, Mahlfeld K, Grasshoff $H$, Allam Y, et al. Comparison of a minimally invasive procedure versus standard microscopic discotomy: a prospective randomised controlled clinical trial. Eur Spine J. 2009;18(7):992-1000.

5. Franzini A, Messina G, Ferroli P, Broggi G. Minimally invasive disc preserving surgery in cervical radiculopathies: the posterior microscopic and endoscopic approach. Acta Neurochir Suppl. 2011;108:197-201.

6. Maiuri $F$, laconetta $\mathrm{G}$, de Divitiis $\mathrm{O}$. The role of intraoperative sonography in reducing invasiveness during surgery for spinal tumors. Minim Invasive Neurosurg. 1997;40(1):8-12.

7. O'Toole JE, Eichholz KM, Fessler RG. Minimally invasive approaches to vertebral column and spinal cord tumors. Neurosurg Clin N Am. 2006;17(4):491-506.

8. Haji FA, Cenic A, Crevier L, Murty N, Reddy K. Minimally invasive approach for the resection of spinal neoplasm. Spine (Phila Pa 1976). 2011;36(15):E1018-26.

9. Naganawa T, Miyamoto K, Hosoe H, Suzuki N, Shimizu K. Hemilaminectomy for removal of extramedullary or extradural spinal cord tumors: medium to long-term clinical outcomes. Yonsei Med J. 2011;52(1):121-9.

10. Sun CX, Meng XL, Xie SN, Yu Y, Yang HJ, Wu B. Unilateral hemilaminectomy for patients with intradural extramedullary tumors. J Zhejiang Univ Sci B. 2011:12(7):575-81.

11. Pompili A, Caroli F, Telera S, Occhipinti E. Minimally invasive resection of intradural-extramedullary spinal neoplasms. Neurosurgery. 2006;59(5):E1152.

12. Uribe JS, Dakwar E, Le TV, Christian G, Serrano S, Smith WD. Minimally invasive surgery treatment for thoracic spine tumor removal: a mini-open, lateral approach. Spine (Phila Pa 1976). 2010;35(Suppl 26):S347-54.

13. Yu Y, Zhang X, Hu F, Xie T, Gu Y. Minimally invasive microsurgical treatment of cervical intraspinal extramedullary tumors. J Clin Neurosci. 2011;18(9):1168-73.

14. Yasuda M, Bresson D, Cornelius JF, George B. Anterolateral approach without fixation for resection of an intradural schwannoma of the cervical spinal canal: technical note. Neurosurgery. 2009:65(6):1178-81.

15. Gerszten PC, Welch WC. Spine: minimally invasive techniques. Prog Neurol Surg. 2006;19:135-51.
16. Mannion RJ, Nowitzke AM, Efendy J, Wood MJ. Safety and efficacy of intradural extramedullary spinal tumor removal using a minimally invasive approach. Neurosurgery. 2011;68(1 Suppl Operative):208-16

17. Sario-glu AC, Hanci M, Bozkus H, Kaynar MY, Kafadar A. Unilateral hemilaminectomy for the removal of the spinal space-occupying lesions. Minim Invasive Neurosurg. 1997:40(2):74-7.

18. Winder MJ, Thomas KC. Minimally invasive versus open approach for cervical laminoforaminotomy. Can J Neurol Sci. 2011;38(2):262-7.

19. Gala VC, O'Toole JE, Voyadzis JM, Fessler RG. Posterior minimally invasive approaches for the cervical spine. Orthop Clin North Am. 2007 ;38(3):339-49.

20. Shchedrenok WV, Ivanenko AV, Sebelev KI, Moguchaia OV. [Minimally invasive surgery of degenerative diseases of the spine]. Vestn Khir Im I I Grek. 2010;169(2):102-4.

21. Wang MY, Levi AD. Minimally invasive lateral mass screw fixation in the cervical spine: initial clinical experience with long-term follow-up. Neurosurgery. 2006;58(5):907-12.

22. Gottfried ON, Dailey AT, Schmidt MH. Adjunct and minimally invasive techniques for the diagnosis and treatment of vertebral tumors. Neurosurg Clin N Am. 2008;19(1):125-38

23. Pompili A, Caroli F, Cattani F, Crecco M, Giovannetti M, Raus $L$, et al. Unilateral limited laminectomy as the approach of choice for the removal of thoracolumbar neurofibromas. Spine (Phila Pa 1976). 2004;29(15):1698-702.

24. Sridhar K, Ramamurthi R, Vasudevan MC, Ramamurthi B. Limited unilateral approach for extramedullary spinal tumours. Br J Neurosurg. 1998;12(5):430-3.

25. Acosta FL Jr, Aryan HE, Chi J, Parsa AT, Ames CP. Modified paramedian transpedicular approach and spinal reconstruction for intradural tumors of the cervical and cervicothoracic spine: clinical experience. Spine (Phila Pa 1976). 2007;32(6):E203-10.

26. Barrey C, Saint-Pierre G, Frappaz D, Hermier M, Mottolese C. Complete removal of an intraspinal and extraspinal cervical chordoma in one stage using the lateral approach. Technical note. J Neurosurg Spine. 2006;5(5):471-5.

27. Ahn DK, Park HS, Choi DJ, Kim KS, Kim TW, Park SY. The surgical treatment for spinal intradural extramedullary tumors. Clin Orthop Surg. 2009;1(3):165-72.

28. Angevine PD, Kellner C, Haque RM, McCormick PC. Surgical management of ventral intradural spinal lesions. J Neurosurg Spine. 2011;15(1):28-37.

29. Wang J, Ou SW, Wang YJ, Wu AH, Wu PF, Wang YB. Microsurgical management of dumbbell $\mathrm{C} 1$ and $\mathrm{C} 2$ schwannomas via the far lateral approach. J Clin Neurosci. $2011 ; 18(2): 241-6$ 